\title{
СТРУКТУРА И ДИНАМИКА НАЛОГОВЫХ ПОСТУПЛЕНИЙ И ИХ ТЕРРИТОРИАЛЬНЫЕ ДИСПРОПОРЦИИ
}

Аннотация: В статье рассматриваются проблемы формирования налоговых доходов и их территориальные диспропорции в дотационных регионах Северо-Кавказского федерального округа (СКФО). Сложившаяся структура налоговых доходов не отвечает интересам стимулирования экономического развития и не способствует расширению налоговой базы дотационных регионов. Исследователь провел комплексный анализ состава и структуры налоговых поступлений в регионах СКФО, в ходе которого использовались методы анализа и синтеза, сводки и группировки, рассчитал в абсолютных величинах налоговую нагрузку, приходящуюся на одного налогоплательщика-организацию. В статье доказана необходимость дифреренцированного подхода к выбору приоритетов региональной налоговой политики в целях снижения дотационности СКФО на основе вовлечения внутренних ресурсов региона в легальные экономические процессы. Для достижения данных целей необходим комплексный подход, учитывающий сложивиуюся структуру экономики и налоговых поступлений, направленный на стимулирование эффективных производств путем системного предоставления налоговых льгот применительно к видам экономической деятельности без привязки к конкретному региону СКФО в целом. Одновременно следует отказаться от льгот непроизводственного характера и не способствующих расширению налогового потенциала территорий. Делается вывод о целесообразности проведение эксперимента путем объявления СКФО территорией экономического развития в рамках Федерального закона от 3 декабря 2011 г. №392-Ф3.

Ключевые слова: налоговые доходы, территориальное развитие, региональный бюджет, налоговая база, налоговые льготы, дотационный регион, налоговое стимулирование, структура налоговых поступлений, региональная налоговая политика, теневая экономика.

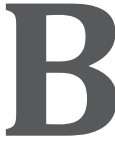

Российской Федерации, согласно Налоговому кодексу Российской Федерации ${ }^{1}$ (далее - НК РФ), действуют следующие виды налогов и сборов: федеральные, региональные и местные. Помимо них, в ст. 18 НК РФ установлены специальные налоговые режимы.

Такая конструкция налогового законодательства означает, прежде всего, разграничение законодательных полномочий в налоговой сфере федеральных органов

\footnotetext{
Налоговый кодекс Российской Федерации. СПС КонсультантПлюс. Интернет портал http://www. consultant.ru/
}

власти, субъектов федерации и местного уровня. Основная налоговая нагрузка на налогоплательщики-организации связана с уплатой федеральных и региональных налогов, а местные налоги как источник доходов не имеют определяющего фискального значения и составляют незначительную часть в налоговых доходах местных бюджетов.

На этом фоне государственная политика в сфере государственных финансов была направлена на расширение финансовой самостоятельности региональных органов власти и муниципалитетов в целях расширения возможностей по укреплению 
доходной базы региональных и местных бюджетов и обеспечения роста поступления налоговых доходов. При этом увеличивались суммы поступлений налогов и сборов во все уровни бюджетной системы страны. Так, в 2011 г. в консолидированный бюджет Российской Федерации было мобилизовано 9720,0 млрд. рублей, что составляет 126,3\% к объему поступлений 2010 года ${ }^{2}$.

Отмечен рост доходов консолидированных бюджетов Российской Федерации практически во всех регионах - 116,9\% — в 2011 году по сравнению с 2010 годом ${ }^{3}$. Одновременно шла работа по списанию накопившейся налоговой задолженности в соответствии с Приказами ФНС России ${ }^{4}$, в рамках которых в 2011 г. была списана задолженность недействующих юридических лиц на сумму свыше 77,7 млрд. рублей 5 .

Наблюдаемые в мировой экономике тенденции вынуждает Россию к перераспределению доходов в пользу федерального бюджета и децентрализации расходных обязательств с одновременной концентрацией налоговых полномочий на федеральном уровне. Вместе с тем, сложившаяся в регионах Российской Федерации структура экономики обуславливает значительную дифференциацию налогового потенциала субъектов и соответственно, структуру налоговых поступлений. Как отмечает М. А. Шилов: «Эта диспропорция порождает массу внутренних экономических и социальных проблем, которые с течением времени только усугубляются. Предпринимаемые

\footnotetext{
2 Официальный сайт ФНС России www.nalog.ru

3 Мониторинг местных бюджетов за 2011 год [Электронный ресурс]-M.: 2012.-Режим доступа-http// www1.minfin.ru/reforms/local government/monitoring/

4 См.: Приказы ФНС России от 19 августа 2010: №ЯК7-8/392@ и №ЯК-7-8/393@.

5 Официальный сайт ФНС России www.nalog.ru
}

меры стимулирования развития территорий через особые экономические зоны, специальные ФЦП и объединение регионов оказываются малоэффективными» ${ }^{6}$. При этом акцентируется внимание на искусственном характере дотационности региональных бюджетов, как фактора обеспечения целостности Российской Федерации. На основе исследования НДС как налога, «несправедливо» зачисляемого в федеральный бюджет, вследствие чего, препятствующего экономическому развитию регионов, автором предлагается введение дифференцированных ставок и гибкой шкалы перераспределения поступлений от НДС в региональные бюджеты, что позволит уменьшить количество дотационных регионов до четырех.

Некорректность предлагаемой методики и погрешности расчетов М. А. Шилова и А.Б. Гусева была доказана в статье Балацкого Е. В. и Екимовой Н. А., которые, предложив уточненную методику, на основе собственных расчетов утверждают, что реализация механизма расщепления НДС в пользу региональных бюджетов способно сократить количество дотационных регионов лишь до трицати трех ${ }^{7}$.

Традиционно, как и в предыдущие годы, наибольшая сумма налоговых и неналоговых поступлений в бюджет обеспечивается налогоплательщиками, осуществляющими предпринимательскую деятельность в Москве: в общей сумме поступлений по Российской Федерации доля Москвы в 2011 году составила 30,2\%.

\footnotetext{
6 Шилов М. А. Гусев А. Б. Искусственная дотационность регионов как залог единства России. Интернетpecypc: http://kapital-rus.ru/articles/article/1010.

7 Балацкий Е.В., Екимова Н.А.Финансовая несостоятельность регионов и совершенствование межбюджетных отношений. //Налоги и финансовое право. 2010. - №4. - C. 317-322.
} 
По словам главы Министерства регионального развития Игоря Слюняева «... сейчас в число доноров входят Татарстан, Москва, Санкт-Петербург, Московская, Ленинградская, Самарская, Сахалинская, Тюменская области, Ненецкий, ХантыМансийский и Ямало-Ненецкий автономные округа» ${ }^{8}$. Далее он продолжает: «...по итогам 2012 года на 15,5\% вырос государственный долг регионов. Это - прямое свидетельство дисбаланса между доходами субъектов Федерации и расходными полномочиями» - подытоживает министр.

В целом признавая полезность научных дискуссий по снижению дотационности регионов, все же отметим, что вопросы распределения вторичны (хотя и взаимообусловлены) по отношению к источникам формирования бюджетных ресурсов, то есть к налоговой базе. Поэтому акцентировать внимание следует на мероприятиях по наращиванию налогового потенциала и вовлечению его в реальные экономические процессы, в том числе, путем гибкой региональной налоговой политики стимулирования экономического развития территорий.

Рассмотрим динамические процессы состава и структуры налоговых поступлений и территориальные диспропорции на примере регионов Северо-Кавказского Федерального округа.

Северо-Кавказский Федеральный округ (далее - СКФО) образован в 2010 году в соответствии с Указом Президента РФ № 82 от 19 января 2010 года. В состав СКФО вошли Республика Дагестан, Республика Ингушетия, Кабардино-Балкарская республика, Карачаево-Черкесская республика, Республика Северная Осетия-Алания, Чеченская республика и Ставрополь-

\footnotetext{
8 Цит. по: Регионы-доноры. Источник: http://rusrand.ru/ events/regiony-donory
}

ский край, с центром федерального округа в Пятигорске. Регионы СКФО занимают 1\% от площади территории Российской Федерации, удельный вес ВРП округа в структуре ВВП России (в 2011 г.) 1,91\%. В структуре налоговых поступлений в целом по России удельный вес составил 1,09\%9.

Основными отличительными особенностями округа являются:

- неразвитая экономическая база и высокий уровень безработицы;

- значительная доля «теневой» экономики в сложившихся секторах экономики (сельское хозяйство, легкая промышленность, пищевая промышленность, туризм);

- высокие террористические и криминальные риски, межэтнические и межрелигиозные конфликты;

- относительно низкий уровень развития базовой и социальной инфраструктуры; - высокий уровень коррупции, клановость и, как следствие, низкая эффективность государственного управления. В силу указанных и множества других обстоятельств, регионы СКФО относятся к дотационным и характеризуются низкими показателями индикаторов социальноэкономического развития по сравнению со среднероссийскими. Основным источником в структуре доходов консолидированных бюджетов традиционно выступает финансовая помощь из федерального бюджета.

Как видно из данных табл. 1 структура доходов консолидированных бюджетов регионов, входящих в СКФО, достаточно неоднородна и удельный вес дотаций колеблется от 38,1\% (Ставропольский край) до $83,8 \%$ в Республике Ингушетия и $86,9 \%$ в Чеченской республике.

\footnotetext{
9 Официальный сайт Федеральной службы госстатистики www.gks.ru
} 
Структура доходов консолидированных бюджетов регионов СКФО в 2011 г., \%

\begin{tabular}{|l|c|c|c|}
\hline \multicolumn{1}{|c|}{ Регионы СкФо } & $\begin{array}{c}\text { Налоговые } \\
\text { доходы }\end{array}$ & $\begin{array}{c}\text { Финансовая } \\
\text { помощь }\end{array}$ & $\begin{array}{c}\text { Прочие } \\
\text { доходы }\end{array}$ \\
\hline Республика Дагестан & 23,1 & 74,1 & 2,8 \\
\hline Республика Ингушетия & 14,9 & 83,8 & 1,3 \\
\hline Кабардино-Балкарская республика & 34,4 & 59,0 & 7,6 \\
\hline Карачаево Черкесская республика & 29,4 & 63,8 & 6,8 \\
\hline Республика Северная Осетия-Алания & 34,7 & 58,9 & 6,4 \\
\hline Чеченская республика & 12,4 & 86,9 & 0,7 \\
\hline Ставропольский край & 49,8 & 38,1 & 12,1 \\
\hline РФ, в среднем & 65,1 & 23,1 & 11,8 \\
\hline
\end{tabular}

(Источник: Официальный сайт Федеральной службы госстатистики www.gks.ru, расчеты автора).

Показатели удельных весов налоговых поступлений,

Таблица 2 администрируемых ФНС России, по регионам СКФО за 2008-2011 гг., \%

\begin{tabular}{|l|c|c|c|c|c|c|c|c|}
\hline \multirow{2}{*}{\multicolumn{1}{|c|}{ Регионы СКФо }} & \multicolumn{4}{|c|}{ Удельный вес, \% } & \multicolumn{4}{c|}{$\begin{array}{c}\text { Налоговая нагрузка, } \\
\text { (поступило/ВРП) }\end{array}$} \\
\cline { 2 - 11 } & $\mathbf{2 0 0 8}$ & $\mathbf{2 0 0 9}$ & $\mathbf{2 0 1 0}$ & $\mathbf{2 0 1 1}$ & $\mathbf{2 0 0 8}$ & $\mathbf{2 0 0 9}$ & $\mathbf{2 0 1 0}$ & $\mathbf{2 0 1 1}$ \\
\hline Республика Дагестан & 17,1 & 16,5 & 16,6 & 16,8 & 0,07 & 0,05 & 0,06 & 0,05 \\
\hline Республика Ингушетия & 1,2 & 1,7 & 1,8 & 2,5 & 0,06 & 0,07 & 0,09 & 0,10 \\
\hline $\begin{array}{l}\text { Кабардино-Балкарская } \\
\text { республика }\end{array}$ & 7,7 & 8,8 & 7,9 & 7,7 & 0,12 & 0,12 & 0,10 & 0,09 \\
$\begin{array}{l}\text { Карачаево-Черкесская } \\
\text { республика }\end{array}$ & 3,4 & 3,9 & 4,2 & 4,5 & 0,09 & 0,09 & 0,09 & 0,09 \\
\hline $\begin{array}{l}\text { Республика Северная } \\
\text { Осетия-Алания }\end{array}$ & 6,7 & 6,9 & 6,4 & 5,7 & 0,11 & 0,09 & 0,08 & 0,07 \\
\hline Чеченская республика & 13,5 & 11,9 & 10,2 & 9,1 & 0,19 & 0,16 & 0,14 & 0,11 \\
\hline Ставропольский край & 50,4 & 50,3 & 52,9 & 53,7 & 0,17 & 0,16 & 0,15 & 0,14 \\
\hline СКФО в целом & 100,0 & 100,0 & 100,0 & 100,0 & 0,13 & 0,11 & 0,11 & 0,10 \\
\hline
\end{tabular}

(Источник: Официальный сайт ФНС России www.nalog.ru, расчеты автора).

Более половины поступлений налогов, сборов и иных обязательных платежей, администрируемых ФНС России, обеспечивает Ставропольский край, как сравнительно наиболее развитый регион СКФО (табл.2): $50,4 \%$ - в 2008 г., $50,3 \%$ - в 2009 г., $52,9 \%$ в 2010 г., 53,7\% - в 2011 г. Существенными являются и поступления второй по зна- чимости региона-Республики Дагестан: $17,1 \%$ - в 2008 г., $16,5 \%$ - в 2009 г., $16,6 \%$ в 2010 г., 16,8\% - в 2011 г.

При этом обращает на себя внимание сопоставимая по отношению к ВРП величина налоговой нагрузки в этих регионах: если в Ставропольском крае она выше среднего по СКФО в 1,3-1,4 раза, то в Республике Да- 


\section{Динамика удельных весов юридических лиц-налогоплательщиков} в разрезе регионов СКФО за 2008-2011 гг., \%

\begin{tabular}{|l|c|c|c|c|}
\hline \multirow{2}{*}{\multicolumn{1}{|c|}{ Регионы СКФо }} & \multicolumn{4}{c|}{ Удельный вес,\% } \\
\cline { 2 - 5 } & $\mathbf{2 0 0 8}$ & $\mathbf{2 0 0 9}$ & $\mathbf{2 0 1 0}$ & $\mathbf{2 0 1 1}$ \\
\hline Республика Дагестан & 21,8 & 22,0 & 22,7 & 23,9 \\
\hline Республика Ингушетия & 3,2 & 3,4 & 3,5 & 3,5 \\
\hline Кабардино-Балкарская республика & 10,2 & 10,4 & 10,1 & 10,3 \\
\hline Карачаево-Черкесская республика & 5,4 & 5,3 & 5,2 & 5,1 \\
\hline Республика Северная Осетия-Алания & 8,7 & 8,7 & 9,1 & 9,2 \\
\hline Чеченская республика & 8,9 & 9,1 & 8,8 & 8,6 \\
\hline Ставропольский край & 41,8 & 41,1 & 40,6 & 39,4 \\
\hline СКФО в целом & 100,0 & 100,0 & 100,0 & 100,0 \\
\hline
\end{tabular}

(Источник: Официальный сайт ФНС России www.nalog.ru, расчеты автора).

гестан - ниже среднего в 2 раза. По этому показателю Дагестан занимает «почетное» первое место среди субъектов СКФО. Аналогичное отставание наблюдается и по показателю налоговых поступлений (по данным 2011 г.) на душу населения (в тыс. руб.): Дагестан - 6,06; Ингушетия - 6,22; КабардиноБалкария - 9,49; Карачаево-Черкессия 10,17; Северная Осетия-Алания - 8,54; Чеченская республика - 7,45; Ставропольский край - 20,37 при среднем значении по Российской Федерации - 67,91 тыс. рублей.

На наш взгляд, выявленные тенденции можно объяснить такими факторами, как количество зарегистрированных налогоплательщиков и сложившаяся в регионе структура экономики.

Наибольшее количество коммерческих организаций - юридических лиц зарегистрировано в Ставропольском крае. Их удельный вес составляет около 40\% от общего количества налогоплательщиков СКФО (табл.3).

По данным таблиц 2 и 3 можно составить сравнительную таблицу взаимосвязей удельных весов: налоговых поступлений, количества налогоплательщиков и налоговой нагрузки (табл. 4).
Из таблицы 4 можно сделать следующие выводы:

1. В Республике Дагестан, несмотря на рост количества налогоплатель-щиковкоммерческих организаций, снижается динамика удельного веса налоговых поступлений на фоне снижения налоговой нагрузки. Это объясняется, во-первых, динамичным ростом недоимки с 763,7 млн. руб. (на 01. 01. 2009 г.) до 5359,9 млн. руб. (на 01.01. 2012 г.), во-вторых, наличием теневого сектора в экономике, оказывающей значительное влияние на социально-экономическое развитие республики. Разумеется, исходя из этого, решение проблемы «обеления экономики», обозначенной в республике как приоритетная, лежит не столько в плоскости совершенствования налогового администрирования, сколько в активизации деятельности уполномоченных органов, призванных пресекать предпринимательскую деятельность без государственной регистрации, а также в тесном сотрудничестве и координации деятельности органов МВД и Службы судебных приставов совместно с налоговыми органами. 


\section{Характеристика взаимосвязей налоговых поступлений, количества налогоплательщиков-организаций и налоговой нагрузки в регионах СКФО за 2008-2011 гг.}

\begin{tabular}{|l|c|c|c|}
\hline \multicolumn{1}{|c|}{ Регионы СкФо } & $\begin{array}{c}\text { Состояние } \\
\text { динамики } \\
\text { удельного веса } \\
\text { налоговых } \\
\text { поступлений }\end{array}$ & $\begin{array}{c}\text { Состояние } \\
\text { динамики } \\
\text { количества нало- } \\
\text { гоплательщиков- } \\
\text { организаций }\end{array}$ & $\begin{array}{r}\text { Состояние } \\
\text { динамики } \\
\text { налоговой } \\
\text { нагрузки }\end{array}$ \\
\hline Республика Дагестан & $\downarrow$ & $\uparrow$ & $\downarrow$ \\
\hline Республика Ингушетия & $\uparrow$ & - & $\downarrow$ \\
\hline $\begin{array}{l}\text { Кабардино-Балкарская } \\
\text { республика }\end{array}$ & - & $\downarrow$ & $\downarrow$ \\
\hline $\begin{array}{l}\text { Карачаево-Черкесская } \\
\text { республика }\end{array}$ & $\uparrow$ & $\uparrow$ & $\downarrow$ \\
\hline $\begin{array}{l}\text { Республика Северная } \\
\text { Осетия-Алания }\end{array}$ & $\downarrow$ & $\downarrow$ & $\downarrow$ \\
\hline Чеченская республика & $\downarrow$ & $\downarrow$ & $\downarrow$ \\
\hline Ставропольский край & $\uparrow$ & $\uparrow$ & $\downarrow$ \\
\hline СКФо в целом & $\uparrow$ & & $\downarrow$ \\
\hline
\end{tabular}

(Обозначения: $\uparrow-$ рост, $\downarrow-$ снижение, - без изменений).

2. В Республике Ингушетия развитие экономики и процессов налогообложения поддается логике: растет количество налогоплательщиков, увеличиваются поступления налогов и сборов, возрастает налоговая нагрузка. Недоимка возросла незначительно: с 216,2 млн. руб. до 225,2 млн. рублей.

3. В Кабардино-Балкарской республике удельные веса налоговых поступлений и количества налогоплательщиков-организаций остались без значимых изменений, но наблюдается снижение налоговой нагрузки, что связано, на наш взгляд, с ростом недоимки с 811,2 млн. руб. (на 01. 01. 2009 г.) до 1423,8 млн. руб. (на 01.01. 2012 г.).

4. В Карачаево-Черкесской республике увеличились налоговые поступления на фоне снижения удельного веса на- логоплательщиков-организаций при неизменной величине налоговой нагрузки. Размер недоимки за анализируемый период возрос с 366,9 млн. руб. до 455,5 млн. рублей.

5. В Республике Северная Осетия-Алания удельный вес налоговых поступлений и величина налоговой нагрузки снижаются на фоне роста удельного веса налогоплательщиков-организаций. Это объясняется, как и выше, ростом недоимки - с 945,8 млн. руб. (на 01. 01. 2009 г.) до 2953,5 млн. рублей (на 01.01. 2012 г.).

Во всех перечисленных пяти регионах удельный вес налоговых поступлений ниже, чем удельный вес количества налогоплательщиков.

6. В Чеченской республике наблюдается динамичное снижение удельных весов 


\section{Динамика поступлений налогов, сборов и иных обязательных платежей в расчете на одного налогоплательщика - коммерческую организацию в регионах СКФО за 2008-2011 гг., /тыс. руб./.}

\begin{tabular}{|l|c|c|c|c|}
\hline \multirow{2}{*}{\multicolumn{1}{c|}{ Регионы СКФо }} & \multicolumn{4}{c|}{$\begin{array}{c}\text { Сумма поступлений в расчете на одну } \\
\text { коммерческую организацию - ор. лицо }\end{array}$} \\
\cline { 2 - 4 } & $\mathbf{2 0 0 8}$ & $\mathbf{2 0 0 9}$ & $\mathbf{2 0 1 0}$ & $\mathbf{2 0 1 1}$ \\
\hline Республика Дагестан & 966,1 & 788,8 & 842,9 & 869,3 \\
\hline Республика Ингушетия & 471,2 & 509,6 & 600,1 & 893,7 \\
\hline Кабардино-Балкарская республика & 936,2 & 897,2 & 896,1 & 924,5 \\
\hline Карачаево-Черкесская республика & 786,6 & 772,3 & 931,2 & 1119,2 \\
\hline Республика Северная Осетия-Алания & 946,4 & 830,0 & 806,5 & 775,4 \\
\hline Чеченская республика & 1491,4 & 1282,3 & 1333,4 & 1320,8 \\
\hline Ставропольский край & 1494,5 & 1295,5 & 1507,1 & 1697,1 \\
\hline СКФО в целом & 1238,4 & 1054,0 & 1153,2 & 1244,6 \\
\hline
\end{tabular}

(Источник: Составлена по данным официальных сайтов Федеральной службы госстатистики www.gks.ru и ФНС России www.nalog.ru, расчеты автора).

налоговых поступлений и количества налогоплательщиков-организаций.

Произошло также снижение сумм недоимки с 1018,6 млн. руб. (на 01.01.2009 г.) до 693,9 млн. руб. (на 01.01. 2012 г.).

7. В Ставропольском крае удельный вес налоговых поступлений возрастает на фоне снижения удельного веса налогоплательщиков-организаций и налоговой задолженности.

Особенностью Чеченской республики и Ставропольского края является то, что в этих регионах удельный вес налоговых поступлений выше, чем удельный вес количества налогоплательщиков.

Если проанализировать суммы налоговых поступлений, уплаченных одним предприятием (за исключением налогов, уплачиваемых физическими лицами), то за анализируемый период они являются наибольшими именно в Ставропольском крае: 1494,5 тыс. руб. - в 2008 г., 1295,5 тыс. руб. — в 2009 г., 1507,1 тыс. руб. — в 2010 г., 1697,1 тыс. руб. - в 2011 г., тогда как в Республике Дагестан одним налогоплатель- щиком уплачивалось от 788,8 тыс. руб. до 966,1 тыс. руб.; в Республике Ингушетия от 471,2 тыс. руб. до 893,7 тыс. руб.; в Кабардино-Балкарской республике - от 896,1 тыс. руб. до 936, 2 тыс. руб.; в Карачаево-Черкесской Республике - от 786,6 тыс. руб. до 1119,2 тыс. руб.; в Северной ОсетииАлании - от 775,4 тыс. руб. до 946.4 тыс. руб.; в Чеченской Республике - от 1282,3 тыс. руб. до 1491,4 тыс. рублей (табл. 5).

Поступления в бюджетную систему от регионов СКФО в 2011 г., за исключением Ставропольского края, колеблются в пределах от 2,5\% - в Республике Ингушетия, до 16,8 \% - в Республике Дагестан при разбросе значений удельных весов юридических лиц-организаций от 3,5 \% - в Республике Ингушетия до 23,9 \% - в Республике Дагестан.

Наибольшие темпы роста количества налогоплательщиков-организаций наблюдаются в Республике Дагестан, где прирост происходил ежегодно: в 2008 г. - на 6,4 \%, в 2009 г. - на 6,9\%, в 2010 г. — на 6,3\%, в 2011 г. - на 7,1 \%. В Чеченской Республи- 
ке в 2010-2011 гг. произошло снижение количества налогоплательщиков-организаций на $0,6 \%$, что и стало одной из причин уменьшения удельного веса этой республики в общей сумме налоговых поступлений в бюджет в течение 2010-2011 гг.

При этом в Республике Дагестан общая сумма поступлений увеличилась на 10,3 $\%$, тогда как в Республике Ингушетия количество налогоплательщиков возросло всего на 1,0 \%, а налоговые поступления возросли в 1,5 раза. В Кабардино-Балкарской Республике количество налогоплательщиков возросло на 3,5 \%, а налоговые поступления увеличились на 6,7 \%. В Карачаево-Черкесской Республике количество налогоплательщиков уменьшилось на $1,6 \%$, однако налоговые поступления возросли на 18,2\%. В Северной Осетии-Алании количество налогоплательщиков-организаций возросло на $2,4 \%$, а налоговые поступления уменьшились на 1,5\%. В Чеченской Республике произошло снижение количества налогоплательщиков на $0,69 \%$ с одновременным снижением налоговых поступлений на 1,6\%. В Ставропольском крае общая сумма налоговых поступлений увеличилась на $11,1 \%$ при уменьшении количества налогоплательщиков-организаций на 1,4 \% за 2010-2011 гг.

Таким образом, более половины налоговых поступлений в регионах СКФО обеспечивает Ставропольский край, причем на увеличение общей суммы налоговых платежей, поступивших в бюджет за 2008-2011 гг. по регионам СКФО, повлияло как изменение количества налогоплательщиков-коммерческих организаций, так и изменение суммы налогов, уплачиваемых одним налогоплательщиком - юридическим лицом.

Как уже было отмечено выше, причины сложившейся ситуации заключаются и в особенностях размещения производительных сил, обусловившей структуру экономики регионов, с «багажом» которой эти регионы вошли в рыночную экономику. В дальнейшем структура экономики становится одним из факторов дифференциации социально-экономического развития регионов при последовательной централизации налоговых полномочий на федеральном уровне.

Отраслевая структура экономики регионов СКФО (по ОКВЭД) пред-ставлена в таблице 6.

Анализ отраслевой структуры формирования ВРП регионов СКФО позволяет выделить следующие особенности:

- значительная доля ВРП формируется в сельском хозяйстве;

- низкие объемы добычи полезных ископаемых, что, впрочем, обусловлено природным фактором;

- отставание доли обрабатывающих производств в ВРП по всем регионам (от $2,5 \%$ - Ингушетия до $14,3 \%$ - КБР) при среднем значении по России $18 \%$;

- высокая доля в ВРП объемов строительства (от 8,8\% - Северная Осетия до $18,8 \%$ - Дагестан) по сравнению со среднероссийским показателем $6,9 \%$;

- от 16,0 \% (Ингушетия) до 27,4\% (Дагестан) ВРП формируется в сфере торговли и обслуживания;

- низкий вклад в ВРП от операций с недвижимостью (от 2,6\% - Дагестан до 5,9\% в Ставропольском крае) при среднем значении по России - 10,6\%;

- высокая доля госсектора (от 6,1 \% Дагестан до 25,1 \% - Ингушетия), при показателе по России 4,7\%.

Перечисленные структурные особенности источников формирования ВРП об- 
Отраслевая структура ВРП регионов СКФО в 2011 г., \%

\begin{tabular}{|c|c|c|c|c|c|c|c|c|}
\hline \multirow[b]{2}{*}{$\begin{array}{c}\text { Группы отраслей } \\
\text { (по ОКВЭД) }\end{array}$} & \multicolumn{7}{|c|}{ Регион СКФО } & \multirow[b]{2}{*}{$\begin{array}{c}\text { РФ } \\
\text { в целом } \\
\text { по сумме } \\
\text { регио- } \\
\text { нов }\end{array}$} \\
\hline & 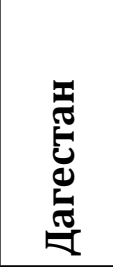 & 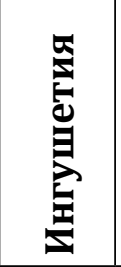 & 茴 & 胥 & 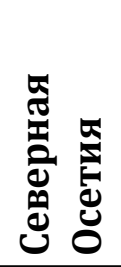 & 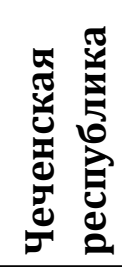 & 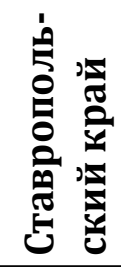 & \\
\hline Сельское хозяйство & 15,1 & 10,4 & 19,1 & 22,2 & 19,3 & 10,4 & 13,0 & 4,7 \\
\hline Рыбоводство, рыболовство & 0,1 & 0,0 & 0,0 & 0,0 & 0,0 & 0,0 & 0,1 & \\
\hline Добыча полезных ископаемых & 0,5 & 2,1 & 0,2 & 1,3 & 0,3 & 2,4 & 0,7 & 11,4 \\
\hline Обрабатывающие производства & 4,2 & 2,5 & 14,3 & 12,5 & 9,7 & 2,5 & 13,7 & 18,0 \\
\hline $\begin{array}{l}\text { Производство и распределение } \\
\text { электроэнергии, газа, воды }\end{array}$ & 1,9 & 2,5 & 4,8 & 5,9 & 4,1 & 0,8 & 5,9 & 4,4 \\
\hline Строительство & 18,8 & 9,9 & 9,9 & 8,1 & 8,8 & 15,8 & 9,9 & 6,9 \\
\hline $\begin{array}{l}\text { Оптовая и розничная торговля, } \\
\text { услуги по ремонту }\end{array}$ & 27,4 & 16,0 & 18,7 & 12,3 & 19,9 & 21,2 & 20,0 & 19,5 \\
\hline Гостиницы и рестораны & 4,6 & 0,2 & 1,1 & 1,0 & 0,8 & 1,5 & 2,1 & 1,0 \\
\hline Транспорт и связь & 8,8 & 7,7 & 6,1 & 5,9 & 9,0 & 6,1 & 9,1 & 10,0 \\
\hline Финансовая деятельность & 0,0 & 1,6 & 0,1 & 0,3 & 0,3 & 0,4 & 0,5 & 0,6 \\
\hline $\begin{array}{l}\text { Операции с недвижимостью, } \\
\text { аренда }\end{array}$ & 2,6 & 3,0 & 3,8 & 5,8 & 4,3 & 3,1 & 5,9 & 10,6 \\
\hline $\begin{array}{l}\text { Государственное управление } \\
\text { и обеспечение безопасности }\end{array}$ & 6,1 & 25,1 & 9,1 & 12,1 & 11,7 & 19,1 & 8,0 & 4,7 \\
\hline Образование & 4,8 & 10,3 & 6,8 & 4,9 & 5,4 & 9,1 & 3,8 & 2,9 \\
\hline Здравоохранение & 3,9 & 7,2 & 4,9 & 6,3 & 5,2 & 6,0 & 6,5 & 3,7 \\
\hline $\begin{array}{l}\text { Прочие коммунальные, социаль- } \\
\text { ные, бытовые услуги }\end{array}$ & 1,2 & 1,5 & 1,1 & 1,4 & 1,2 & 1,6 & 0,8 & 1,4 \\
\hline Итого & 100,0 & 100,0 & 100,0 & 100,0 & 100,0 & 100,0 & 100,0 & 100,0 \\
\hline
\end{tabular}

(Источник: Отраслевая структура валовой добавленной стоимости субъектов Российской Федерации в 2011 году. - Электронный ресурс. - Режим доступа: http://www.gks.ru/free doc/new site/vvp/otrstru11.xls, расчеты автора).

уславливают и территориальные диспропорции налоговых поступлений.

Отраслевая структура налоговых поступлений в бюджетную систему по регионам СКФО представлена в таблице 7.

Из данных табл. 7 видно, что наибольший процент налоговых поступлений по СКФО приходится на обрабатывающие производства - $17,7 \%$ (17,4\% - в целом по
России). При этом максимальное значение данного показателя наблюдается в Кабардино-Балкарии $(26,6 \%)$, минимальное в Чеченской республике $(0,7 \%)$. Следующей отраслью (по ОКВЭД) выступает «государственное управление и обеспечение безопасности»: при среднем значении по РФ $2,5 \%$ средний показатель по СКФО составил $11,9 \%$. При этом максимальное значе- 


\section{Структура налоговых поступлений по отраслям ( по ОКВЭД)} экономики регионов СКФО в 2011 г., \%

\begin{tabular}{|c|c|c|c|c|c|c|c|c|c|}
\hline \multirow[b]{2}{*}{$\begin{array}{c}\text { Группы отраслей (по ОК- } \\
\text { ВЭД) }\end{array}$} & \multicolumn{7}{|c|}{ Регион СКФО } & \multirow{2}{*}{ 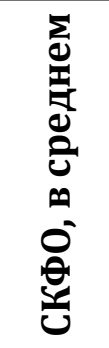 } & \multirow[b]{2}{*}{$\begin{array}{c}\text { Спра- } \\
\text { вочно: } \\
\text { по РФ }\end{array}$} \\
\hline & 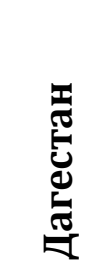 & 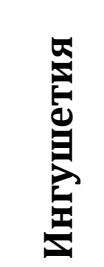 & 嶑 & 承 & 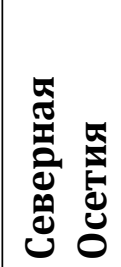 & 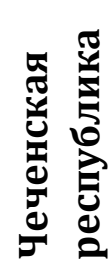 & 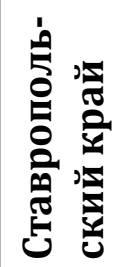 & & \\
\hline Сельсн & 0,8 & 0,7 & 0,02 & 3,2 & 0,7 & 0,0 & 4,1 & 2,5 & 0,5 \\
\hline Рыбоводство, рыболо & 0,08 & 0,0 & 0,01 & 0,01 & 0,03 & 0,0 & 0,03 & 0,03 & 0,1 \\
\hline Добыча полезных & 5,4 & 28,7 & 0,6 & 4,8 & 0,8 & 38,9 & 8,3 & 9,9 & 28,2 \\
\hline Обрабатывающие пр & 18,3 & 1,3 & 26,6 & 19,7 & 18,9 & 0,7 & 19,4 & 17,7 & 17,4 \\
\hline $\begin{array}{l}\text { Произв } \\
\text { электр }\end{array}$ & 9,6 & 3,8 & 14,1 & 16,6 & 10,4 & 0,06 & 9,9 & 9,5 & 3,2 \\
\hline Строительство & 4,2 & 7,2 & 2,6 & 4,7 & 9,8 & 10,4 & 5,4 & 5,8 & 5,3 \\
\hline $\begin{array}{l}\text { Оптовая } \\
\text { ля, услуг }\end{array}$ & 2,6 & 3,6 & 7,4 & 10,0 & 8,2 & 0,6 & 11,3 & 6,9 & 10,3 \\
\hline Гостиницы и рест & 0,26 & 0,04 & 0,6 & - & 0,9 & 0,04 & 0,5 & 0,5 & 0,7 \\
\hline Транс & 13,2 & 5,9 & 5,9 & 5,4 & 7,7 & 5,7 & 11,1 & 10,2 & 7,6 \\
\hline Фина & 4,2 & 4,5 & 5,8 & 5,1 & 6,1 & 3,2 & 5,6 & 5,3 & 4,6 \\
\hline $\begin{array}{l}\text { Операции с недвижимостью, } \\
\text { аренда }\end{array}$ & 7,1 & 2,4 & 4,3 & 5,9 & 0,0 & 2,7 & 8,2 & 6,2 & 11,3 \\
\hline $\begin{array}{l}\text { Государственное управление и } \\
\text { обеспечение безопасности }\end{array}$ & 19,5 & 27,9 & 13,5 & 13,7 & 21,6 & 23,3 & 5,2 & 11,9 & 2,5 \\
\hline Образование & 7,0 & 6,1 & 9,2 & 4,7 & 7,3 & 5,6 & $3, \varepsilon$ & 5,3 & 1,9 \\
\hline Здравоохранение & 4,9 & 5,5 & 6,3 & 3,7 & 6,3 & 2,2 & 4,6 & 4,7 & 1,5 \\
\hline $\begin{array}{l}\text { Прочие коммунальные, соци- } \\
\text { альные, бытовые услуги }\end{array}$ & 2,86 & 2,36 & 3,07 & 2,49 & 1,27 & 6,6 & 2,57 & 3,57 & 4,9 \\
\hline Итого & 100,0 & 100,0 & 100,0 & 100,0 & 100,0 & 100,0 & 100,0 & 100,0 & 100,0 \\
\hline
\end{tabular}

(Источник: Официальный сайт ФНС России www.nalog.ru, расчеты автора).

ние в Республике Ингушетия - 27,9\%, минимальное - 5,2\% в Ставропольском крае. Аналогичные тенденции наблюдаются и в сферах образования и здравоохранения: здесь тоже сопоставимые показатели выше среднероссийских. Существенными являются и поступления от добычи полезных ископаемых - 9,9\%, производства, распределения электроэнергии, газа, воды 9,5\%. Остальные показатели находятся в пределах от 0,03\% (рыбоводство, рыболовство) до 6,9\% (оптовая и розничная торговля).

По данным таблицы 7 проведем ранжировку регионов СКФО, исходя из среднего значения по Российской Федерации (табл. 8).

Таким образом, межрегиональные различия в отраслевой структуре налоговых поступлений в значительной мере связаны с уровнем социально-экономического 
Группировка регионов СКФО, исходя из средней доли налоговых поступлений по РФ, в разрезе отраслей (по ОКВЭД) в 2011 г., \%

\begin{tabular}{|c|c|c|c|c|c|}
\hline $\begin{array}{c}\text { Группы отраслей } \\
\text { (по ОКВЭД) }\end{array}$ & $\begin{array}{l}\theta \\
0 \\
0 \\
0 \\
0 \\
0 \\
0 \\
0 \\
0 \\
0 \\
0 \\
0\end{array}$ & 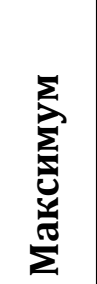 & $\begin{array}{c}\text { Регины } \\
\text { с максимальным } \\
\text { значением }\end{array}$ & $\sum_{\sum}^{\sum}$ & $\begin{array}{c}\text { Регионы } \\
\text { с минимальным } \\
\text { значением }\end{array}$ \\
\hline Сельское хозяйство & 0,5 & 4,1 & Ставропольский край & 0,0 & Чеченская республика \\
\hline $\begin{array}{l}\text { Рыбоводство, } \\
\text { рыболовство }\end{array}$ & 0,1 & 0,08 & Республика Дагестан & 0,0 & $\begin{array}{l}\text { Республика Ингушетия, } \\
\text { Чеченская республика }\end{array}$ \\
\hline $\begin{array}{l}\text { Добыча полезных } \\
\text { ископаемых }\end{array}$ & 28,2 & 38,9 & Чеченская республика & 0,6 & $\begin{array}{l}\text { Кабардино-Балкарская } \\
\text { республика }\end{array}$ \\
\hline $\begin{array}{l}\text { Обрабатывающие } \\
\text { производства }\end{array}$ & 17,4 & 26,6 & $\begin{array}{l}\text { Кабардино-Балкарская } \\
\text { республика }\end{array}$ & 0,7 & Чеченская республика \\
\hline $\begin{array}{l}\text { Производство и распре- } \\
\text { деление электроэнер- } \\
\text { гии, газа, воды }\end{array}$ & 3,2 & 16,6 & $\begin{array}{l}\text { Карачаево-Черкесская } \\
\text { республика }\end{array}$ & 0,06 & Чеченская республика \\
\hline Строительство & 5,3 & 10,4 & Чеченская республика & 2,6 & $\begin{array}{l}\text { Кабардино-Балкарская } \\
\text { республика }\end{array}$ \\
\hline $\begin{array}{l}\text { Оптовая и розничная } \\
\text { торговля, услуги } \\
\text { по ремонту } \\
\end{array}$ & 10,3 & 11,3 & Ставропольский край & 2,6 & Республика Дагестан \\
\hline Гостиницы и рестораны & 0,7 & 0,9 & Северная Осетия-Алания & 0,0 & $\begin{array}{l}\text { Карачаево-Черкесская } \\
\text { республика }\end{array}$ \\
\hline Транспорт и связь & 7,6 & 13,2 & Республика Дагестан & 5,4 & $\begin{array}{l}\text { Карачаево-Черкесская } \\
\text { республика }\end{array}$ \\
\hline $\begin{array}{l}\text { Финансовая деятель- } \\
\text { ность }\end{array}$ & 4,6 & 6,1 & Северная Осетия-Алания & 3,2 & Чеченская республика \\
\hline $\begin{array}{l}\text { Операции с недвижимо- } \\
\text { стью, аренда }\end{array}$ & 11,3 & 8,2 & Ставропольский край & 0,0 & Северная Осетия-Алания \\
\hline $\begin{array}{l}\text { Государственное управ- } \\
\text { ление и обеспечение } \\
\text { безопасности }\end{array}$ & 2,5 & 27,9 & Республика Ингушетия & 5,2 & Ставропольский край \\
\hline Образование & 1,9 & 9,2 & $\begin{array}{l}\text { Кабардино-Балкарская } \\
\text { республика }\end{array}$ & 3,8 & Ставропольский край \\
\hline Здравоохранение & 1,5 & 6,3 & Северная Осетия-Алания & 2,2 & Чеченская республика \\
\hline $\begin{array}{l}\text { Прочие коммунальные, } \\
\text { социальные, бытовые } \\
\text { услуги }\end{array}$ & 4,9 & 6,6 & Чеченская республика & 1,27 & Северная Осетия-Алания \\
\hline
\end{tabular}

(Источник: Официальный сайт ФНС России www.nalog.ru, группировка автора). 
развития регионов. Другим существенным фактором, влияющим на уровень налоговых поступлений является природно-ресурсный потенциал, обуславливающий специализацию региона (например, Чеченская республика - добыча углеводородов, Ставропольский край - сельское хозяйство, Кабардино-Балкарская республика пищевая промышленность).

Следовательно, как видно из результатов проведенного анализа, высокий уровень налогообложения характерен для эффективных отраслей, что свидетельствует о дискриминационном характере государства к предприятиям рентабельных отраслей. Это приводит к тому, что самые эффективные предприятия не заинтересованы в расширении объемов своей легальной деятельности и увеличении рабочих мест, а стремятся к дроблению бизнеса и применению различных схем ухода от налогообложения, вплоть до перехода в теневой сектор.

В результате реализации государством такой налоговой политики в экономике России в течение последних лет наблюдается увеличение количества неэффективных предприятий, а также падение темпов экономического развития, вследствие чего растут объемы недоимки в бюджет в ведущих отраслях экономики регионов.

Тенденции образования и роста недоимки в бюджет формирует ситуацию, когда финансовые ресурсы хозяйствующих субъектов распределяются в пользу неэффективных предприятий, позволяя тем самым и в дальнейшем осуществлять им предпринимательскую деятельность, независимо от показателей финансово-хозяйственной деятельности, расширяя теневой сектор и объемы коррупции. В связи с этим, предприятия отдельных отраслей, деятельность которых является легальной и эффективной, несут большую налоговую нагрузку, уплачивая значительно большие суммы налогов в бюджет.

Результаты анализа свидетельствуют о наличии процессов структурной деформации в источниках формирования налоговых баз и налоговых поступлений. Значительный удельный вес ВРП формируют такие отрасли, как оптовая и розничная торговля, строительство. Однако существенную долю налоговых поступлений обеспечивают обрабатывающие производства, госсектор - государственное управление, обеспечение безопасности, транспорт и связь.

Данные табл. 9 и 10 характеризуют структуру налоговых поступлений и их региональные различия. Анализ подтверждает отмеченные выше тенденции, то есть больше половины налоговых доходов обеспечивает Ставропольский край. Так, по налогу на прибыль в 2011 г. обеспечено более $55,6 \%$ поступлений организациями, осуществляющими предпринимательскую деятельность в Ставропольском крае. Вместе с тем, в 2010-2011 гг. произошло снижение удельного веса на 4,3 п.п. Значительные суммы этого налога обеспечивает Республика Дагестан - 17,1\%. Здесь тоже заметны тенденции снижения доли налога на прибыль организаций по сравнению с 2010 г. на 2,9 п.п.

Аналогичные тенденции характерны и для НДФЛ. Наиболее значимые поступления обеспечивают Ставропольский край $(44,5 \%)$, Республика Дагестан $(17,4 \%)$ и Чеченская республика $(13,5 \%)$, что связано с высокой долей занятых в госсекторе-государственное управление и обеспечение безопасности.

Около 92 \% поступлений НДС в 2011 г. обеспечили Ставропольский край $(82,0 \%)$ и Республика Дагестан (9,7\%), причем за 


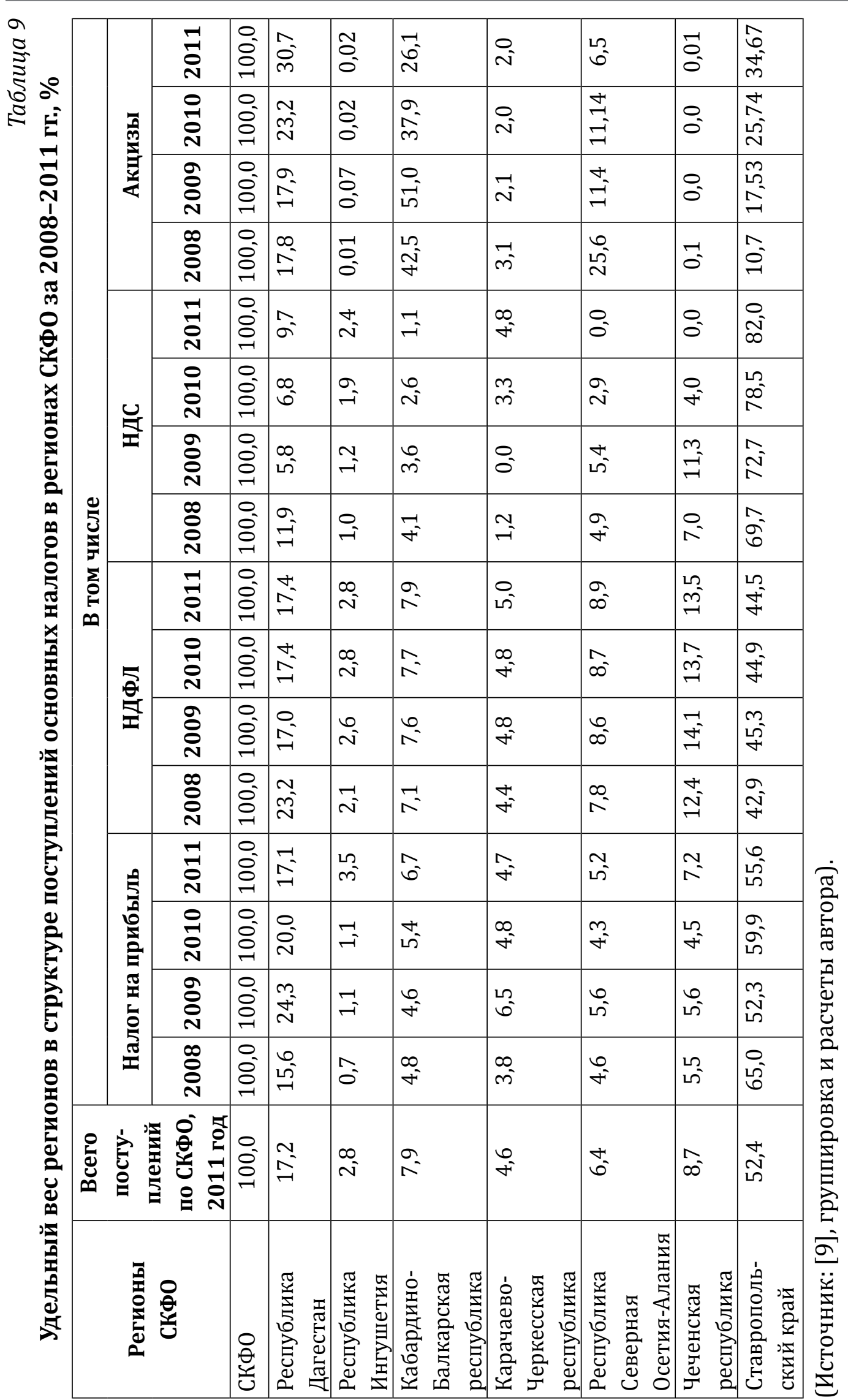


Структура поступлений по видам налоговых доходов

в разрезе регионов СКФО в 2011 г., \%

\begin{tabular}{|c|c|c|c|c|c|}
\hline Виды налогов & 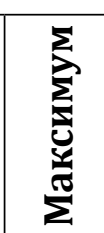 & Регионы & 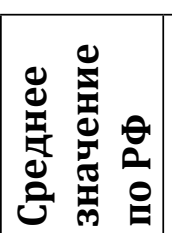 & $\sum_{\sum}^{\sum}$ & Регионы \\
\hline $\begin{array}{l}\text { Налог на прибыль } \\
\text { организаций }\end{array}$ & 30,0 & $\begin{array}{l}\text { Республика } \\
\text { Ингушетия }\end{array}$ & 23,7 & 15,5 & Чеченская республика \\
\hline НДФЛ & 54,9 & $\begin{array}{l}\text { Республика Северная } \\
\text { Осетия-Алания }\end{array}$ & 20,8 & 31,4 & Ставроп \\
\hline НДС & 17,9 & Ставропольский край & 18,3 & - & $\begin{array}{l}\text { Чеченская республика, } \\
\text { Республика Северная } \\
\text { Осетия-Алания }\end{array}$ \\
\hline Акцизы & 19,6 & $\begin{array}{l}\text { Кабардино-Балкар- } \\
\text { ская республика }\end{array}$ & 6,3 & 0,0 & Чеченская республика \\
\hline НДПИ & 27,7 & Чеченская республика & 21,3 & 0,1 & $\begin{array}{l}\text { Кабардино-Балкарская } \\
\text { республика }\end{array}$ \\
\hline $\begin{array}{l}\text { Налог на имущество } \\
\text { организаций }\end{array}$ & 9,6 & $\begin{array}{l}\text { Карачаево-Черкесская } \\
\text { республика }\end{array}$ & 4,9 & 3,8 & Чеченская республика \\
\hline Земельный налог & 4,2 & $\begin{array}{l}\text { Кабардино-Балкар- } \\
\text { ская республика }\end{array}$ & 1,3 & 0,2 & Чеченская республика \\
\hline $\begin{array}{l}\text { Транспортный } \\
\text { налог }\end{array}$ & 1,4 & $\begin{array}{l}\text { Карачаево-Черкесская } \\
\text { республика }\end{array}$ & 0,9 & 0,3 & Чеченская республика \\
\hline $\begin{array}{l}\text { Налог на имущество } \\
\text { физических лиц }\end{array}$ & 0,5 & Республика Дагестан & 0,06 & 0,0 & Республика Ингушетия \\
\hline $\mathrm{YCH}$ & 5,6 & $\begin{array}{l}\text { Республика Северная } \\
\text { Осетия-Алания }\end{array}$ & 1,7 & 0,6 & Чеченская республика \\
\hline ЕНВД & 3,1 & $\begin{array}{l}\text { Республика Северная } \\
\text { Осетия-Алания }\end{array}$ & 0,7 & 0,5 & Чеченская республика \\
\hline $\mathrm{ECxH}$ & 0,25 & Ставропольский край & 0,04 & 0,0 & Республика Ингушетия \\
\hline
\end{tabular}

(Источник: Официальный сайт ФНС России www.nalog.ru, группировка и расчеты автора).

2009-2011 гг. в обоих регионах динамика положительная.

В структуре поступлений акцизов со значительным отрывом лидируют регионы, выпускающие подакцизную продукцию: Ставропольский край (34,67\%), Республика Дагестан (30,7\%) и КабардиноБалкарская республика $(26,1 \%)$. Однако, в отличие от Ставропольского края и Республики Дагестан, где доля акцизов возросла с $10,7 \%$ до $34,67 \%$ и с $17,8 \%$ до $30,7 \%$ (за 2008-2011 гг.) соответственно, в Кабардино-Балкарской республике динамика отрицательная - доля акцизов уменьшилась с $42,5 \%$ до $26,1 \%$.

Несмотря на положительную динамику поступлений в бюджетную систему, в экономике регионов СКФО есть проблема бессистемного предоставления значительного количества налоговых льгот. Так, 
по словам главы Минфина А. Силуанова «...одной из основных причин высокой зависимости от помощи федерального правительства является то, что власти регионов дают слишком много льгот по региональным и местным налогам. Если в среднем по РФ налоговые доходы регионов составляют 21,5\% от их ВРП, то на Северном Кавказе - всего 10\%. Консолидированный бюджет СКФО не получил изза преференций только в прошлом году (2012г. - авт.) 7,3 млрд руб. - это более 6\% налоговых доходов округа. Больше всего потерь от льгот по транспортному налогу и налогу на имущество. В некоторых регионах СКФО транспортный налог платят всего 40\% автовладельцев. Общий объем льгот по этому налогу составляет 3,2 миллиардарублей. Из-за этого отдача от одного авто в округе - 466 руб. при средней по стране 2000 руб. В ряде регионов льготы по налогу на имущество действуют в отношении почти 90\% всех налогоплательщиков. Это практически освобождение от этого налога» ${ }^{10}$.

Однако в структуре налоговых поступлений в разрезе регионов картина иная. Так, в структуре налоговых поступлений в Республике Ингушетия наибольшая доля в 2011 г. обеспечена за счет налога на прибыль организаций - 30,0\%, наименьшая-в Республике Чечня - 15,5\%, при среднем значении по Российской Федерации 23,7\%.

В Республике Северная Осетия - Алания более половины (54,9\%) налоговых доходов обеспечивается за счет НДФЛ, замыкает с 31,4\% Ставропольский край, при среднем значении по России 20,8\%.

\footnotetext{
10 Регионы Северного Кавказа дают слишком много налоговых льгот. Российский налоговый портал http:// taxpravo.ru/
}

По НДС с 17,9\% лидирует Ставропольский край при среднем значении по России 18,3\%. В Чеченской Республике и республике Северная Осетия-Алания суммы предъявленных налоговых вычетов по НДС превысили объемы поступлений.

По акцизам лидирует с 19,6\% Кабардино-Балкарская республика, среднее по России - 6,3\% при нулевом значении по Чеченской республике.

Зато в лидеры со значением 27,7\% по НДПИ в структуре налоговых поступлений по региону вышла Чеченская республика, при среднем значении по России 21,3\%. Меньше всего доля НДПИ в структуре налоговых поступлений в Кабардино-Балкарской республике.

Учитывая все вышеизложенное, считаем объективно необходимым пересмотреть региональную налоговую политику в регионах СКФО и усовершенствовать ее в следующих направлениях.

1. Вовлечение в развитие экономики внутренних ресурсов региона через налоговые механизмы. При этом привязать условия и механизмы налогового стимулирования к конкретным результатам производственной (увеличение объемов производства), инвестиционной (рост инвестиций) и социальной (увеличение количества стационарных рабочих мест) деятельности.

2. Необходимо обеспечить расширение региональной налоговой базы на основе выработки четкой стратегии противодействия теневой экономике и вовлечения в легальные экономические процессы. Этому процессу могла бы способствовать, помимо системы налоговых льгот для эффективных производств всего региона в целом, также и разьяснительная работа, суть которой заключается в формировании атмос- 
феры нетерпимости к неплательщикам налогов и стимулирования деятельности, осуществляемой в рамках российского законодательства.

3. В отношении регионов СКФО необходимо разработать и реализовать гибкую финансово-бюджетную политику, руководствуясь правилом: лучше дать удочку, чем постоянно кормить рыбой. Правовая база такой политики в России уже разработана ${ }^{11}$ и регионы СКФО могли бы стать экспериментальной площадкой по созданию территорий экономического развития. При этом должна быть решена задача рационализации структуры ВРП путем сти- мулирования межрегионального распределения капитала в эффективные производства. В системе показателей состоятельности эксперимента целесообразно учесть фискальный эффект, выражающийся в динамике налоговых поступлений, в том числе и от проектов, при реализации которых были предоставлены налоговые льготы.

При обосновании стратегии региональной налоговой политики необходимо ориентироваться на учет очень разных по содержанию и действию факторов, которые оказывают влияние на формирование базы налогообложения в регионах и уровень их экономического развития.

\section{Библиография:}

1. Налоговый кодекс РФ. СПС КонсультантПлюс. http://www.consultant.ru/

2. Федеральный закон от 3 декабря 2011 г. №392-Ф3 «0 зонах территориального развития в Российской Федерации и о внесении изменений в отдельные законодательные акты Российской Федерации», (в ред. Федерального закона от 28.12.2013 №407-Ф3).

3. Приказы ФНС России от 19 августа 2010: №ЯК-7-8/392@, №ЯК-7-8/393@.

4. Балацкий Е.В., Екимова Н.А.Финансовая несостоятельность регионов и совершенствование межбюджетных отношений. //Налоги и финансовое право. - 2010. — №4. - C. 317-322.

5. Валиева Д.Г. Межбюджетные трансферты и политика региональных властей в условиях высокой дотационности регионов // Вопросы государственного и муниципального управления, 2011. №4.

6. Джурбина Е. М., Фатеев Д. И. Анализ возможностей балансирования финансовых потоков в межбюжетных отношениях регионов СКФО // Финансы и кредит (60) УЭкС, 12/2013. Дата публикации 30.12. 2013.

7. Мониторинг местных бюджетов за 2011 год [Электронный ресурс] — M.: 2012. — Peжим доступа-http//www1.minfin.ru/reforms/local government/monitoring/

8. Отраслевая структура валовой добавленной стоимости субъектов Российской Федерации в 2011 году. - Электронный ресурс. - Режим доступа: http://www.gks.ru/free doc/new site/vvp/otr-stru11.xls.

9. Официальный сайт Федеральной службы госстатистики www.gks.ru

\footnotetext{
11 Федеральный закон от 3 декабря 2011 г. №392-Ф3 «О зонах территориального развития в Российской Федерации и о внесении изменений в отдельные законодательные акты Российской Федерации», (в ред. Федерального закона от 28.12.2013 №407-Ф3).
} 
10. Официальный сайт ФНС России www.nalog.ru

11. Поступление налогов, сборов и иных обязательных платежей в консолидированный бюджет Российской Федерации по стоянию на 1 января 2012 года / Форма 1-НМ. [Электронный ресурс]. - Режим доступа: http://www.nalog.ru/html/docs/030412.rar.

12. Регионы-доноры. Источник: http://rusrand.ru/events/regiony-donory

13. Регионы России. Социально-экономические показатели-2012: Статистический сборник. - М.: Росстат, 2012.

14. Регионы Северного Кавказа дают слишком много налоговых льгот. Российский налоговый портал http://taxpravo.ru/

15. Финансы России 2012: статистический сборник. - М.: Росстат, 2012.

16. Шилов М. А. Гусев А. Б. Искусственная дотационность регионов как залог единства России. Интернет-ресурс: http://kapital-rus.ru/articles/article/1010.

17. Шемякина М.С. Генезис категории «налоговый потенциал» // Налоги и налогообложение. - 2013. - 9. - С. 689-704. DOI: 10.7256/1812-8688.2013.9.9654.

18. О. Н. Савина, Ю. В. Малкова Мониторинг эффективности системы налоговых инструментов стимулирования развития инновационной экономики в условиях действующего законодательства и направления его совершенствования // Налоги и налогообложение. - 2012. - 4. - С. 24-34.

19. Л. С. Кирина Использование имитационного моделирования в системе государственного налогового прогнозирования и планирования // Налоги и налогообложение. 2012. - 1. - С. 4-7.

20. Никиткова У.О. Об эффективности практики местного налогообложения // Налоги и налогообложение. - 2013. - 12. - C.877-884. DOI: 10.7256/1812-8688.2013.12.10238.

21. Никиткова У.О. Об оптимизации предоставления налоговых льгот по имущественным налогам // Налоги и налогообложение. - 2013. - 11. - C. 825-833. DOI: 10.7256/1812-8688.2013.11.10243.

22. Никифорова А.В. Правовые позиции органов конституционной юстиции по вопросам территориальной организации местного самоуправления // NB: Вопросы права и политики. - 2012. - 1. - C. 69-91. URL: http://www.e-notabene.ru/lr/article_29.html

23. Павельева Н.С., Королева Л.П.. Проблемы и перспективы укрепления финансовой самостоятельности территориальных бюджетов в РФ. // Налоги и налогообложение. 2014. — № 1. — C. 49-56. DOI: .10.7256/1812-8688.2014.1.10969

24. Кучерявенко Н.П.. Согласование родовых и видовых конструкций при регулировании бюджетных доходов. // Финансовое право и управление. - 2014. - № 1. - С. 120140. DOI: .10.7256/2310-0508.2014.1.9886

25. Агузарова Л.А.. Налоговый потенциал региона и повышение эффективности планирования налоговых доходов (на материалах РСО-Алания). // Налоги и налогообложение. - 2013. - № 11. - С. 818-824. DOI: .10.7256/1812-8688.2013.11.10054

26. Сугарова И.В.. К вопросу о сущностных характеристиках налогового потенциала региона. // Налоги и налогообложение. - 2013. - № 10. - C. 723-729. DOI: .10.7256/18128688.2013.10.10124

27. Д.М. Мошкова. О налоговом регулировании инновационной деятельности в РФ. // Финансовое право и управление. - 2013. - № 1. - C. 105-110. DOI: .10.7256/.2013.1.952 


\section{References:}

1. Nalogovyi kodeks RF. SPS Konsul'tantPlyus. http://www.consultant.ru/

2. Federal'nyi zakon ot 3 dekabrya 2011 g. №392-FZ «O zonakh territorial'nogo razvitiya $\mathrm{v}$ Rossiiskoi Federatsii i o vnesenii izmenenii $\mathrm{v}$ otdel'nye zakonodatel'nye akty Rossiiskoi Federatsii», (v red. Federal'nogo zakona ot 28.12.2013 №407-FZ).

3. Prikazy FNS Rossii ot 19 avgusta 2010: №YaK-7-8/392@, №YaK-7-8/393@.

4. Balatskii E.V., Ekimova N.A.Finansovaya nesostoyatel'nost' regionov i sovershenstvovanie mezhbyudzhetnykh otnoshenii. //Nalogi i finansovoe pravo. - 2010. — №4. - S. 317-322.

5. Valieva D.G. Mezhbyudzhetnye transferty i politika regional'nykh vlastei v usloviyakh vysokoi dotatsionnosti regionov // Voprosy gosudarstvennogo i munitsipal'nogo upravleniya, 2011. №4.

6. Dzhurbina E. M., Fateev D. I. Analiz vozmozhnostei balansirovaniya finansovykh potokov v mezhbyuzhetnykh otnosheniyakh regionov SKFO // Finansy i kredit (60) UEkS, 12/2013. Data publikatsii 30.12. 2013.

7. Monitoring mestnykh byudzhetov za 2011 god [Elektronnyi resurs] - M.: 2012. — Rezhim dostupa-http//www1.minfin.ru/reforms/local government/monitoring/

8. Otraslevaya struktura valovoi dobavlennoi stoimosti sub"ektov Rossiiskoi Federatsii v 2011 godu. - Elektronnyi resurs. - Rezhim dostupa: http://www.gks.ru/free doc/new site/ vvp/otr-stru11.xls.

9. Ofitsial'nyi sait Federal'noi sluzhby gosstatistiki www.gks.ru

10. Ofitsial'nyi sait FNS Rossii www.nalog.ru

11. Postuplenie nalogov, sborov i inykh obyazatel'nykh platezhei v konsolidirovannyi byudzhet Rossiiskoi Federatsii po stoyaniyu na 1 yanvarya 2012 goda / Forma 1-NM. - [Elektronnyi resurs]. - Rezhim dostupa: http://www.nalog.ru/html/docs/030412.rar.

12. Regiony-donory. Istochnik: http://rusrand.ru/events/regiony-donory

13. Regiony Rossii. Sotsial'no-ekonomicheskie pokazateli-2012: Statisti-cheskii sbornik. - M.: Rosstat, 2012.

14. Regiony Severnogo Kavkaza dayut slishkom mnogo nalogovykh l'got. Rossiiskii nalogovyi portal http://taxpravo.ru/

15. Finansy Rossii 2012: statisticheskii sbornik. - M.: Rosstat, 2012.

16. Shilov M. A. Gusev A. B. Iskusstvennaya dotatsionnost' regionov kak zalog edinstva Rossii. Internet-resurs: http://kapital-rus.ru/articles/article/1010.

17. Shemyakina M.S. Genezis kategorii «nalogovyi potentsial» // Nalogi i nalogooblozhenie. 2013. - 9. - C. 689-704. DOI: 10.7256/1812-8688.2013.9.9654.

18. O. N. Savina, Yu. V. Malkova Monitoring effektivnosti sistemy nalogovykh instrumentov stimulirovaniya razvitiya innovatsionnoi ekonomiki $\mathrm{v}$ usloviyakh deistvuyushchego zakonodatel'stva i napravleniya ego sovershenstvovaniya // Nalogi i nalogooblozhenie. 2012. - 4. - C. 24-34.

19. L. S. Kirina Ispol'zovanie imitatsionnogo modelirovaniya v sisteme gosudarstvennogo nalogovogo prognozirovaniya i planirovaniya // Nalogi i nalogooblozhenie. - 2012. - 1. C. 4-7.

20. Nikitkova U.O. Ob effektivnosti praktiki mestnogo nalogooblozheniya // Nalogi i nalogooblozhenie. - 2013. - 12. - C. 877-884. DOI: 10.7256/1812-8688.2013.12.10238. 
21. Nikitkova U.O. Ob optimizatsii predostavleniya nalogovykh l'got po imushchestvennym nalogam // Nalogi i nalogooblozhenie. - 2013. - 11. - C. 825-833. DOI: 10.7256/18128688.2013.11.10243.

22. Nikiforova A.V. Pravovye pozitsii organov konstitutsionnoi yustitsii po voprosam territorial'noi organizatsii mestnogo samoupravleniya // NB: Voprosy prava i politiki. 2012. - 1. - C. 69-91. URL: http://www.e-notabene.ru/lr/article_29.html

23. Pavel'eva N.S., Koroleva L.P..Problemy i perspektivyukrepleniya finansovoi samostoyatel'nosti territorial'nykh byudzhetov v RF. // Nalogi i nalogooblozhenie. — 2014. — № 1. - C. 49-56. DOI: .10.7256/1812-8688.2014.1.10969

24. Kucheryavenko N.P.. Soglasovanie rodovykh i vidovykh konstruktsii pri regulirovanii byudzhetnykh dokhodov. // Finansovoe pravo i upravlenie. — 2014. — № 1. - C. 120-140. DOI: .10.7256/2310-0508.2014.1.9886

25. Aguzarova L.A.. Nalogovyi potentsial regiona i povyshenie effektivnosti planirovaniya nalogovykh dokhodov (na materialakh RSO-Alaniya).// Nalogi i nalogooblozhenie. - 2013. № 11. — C. 818-824. DOI: .10.7256/1812-8688.2013.11.10054

26. Sugarova I.V.. K voprosu o sushchnostnykh kharakteristikakh nalogovogo potentsiala regiona. // Nalogi i nalogooblozhenie. — 2013. — № 10. — C. 723-729. DOI:.10.7256/18128688.2013.10.10124

27. D.M. Moshkova. O nalogovom regulirovanii innovatsionnoi deyatel'nosti v RF. // Finansovoe pravo i upravlenie. — 2013. — № 1. — C. 105-110. DOI: .10.7256/.2013.1.952 